\title{
Temporary Cable Force Monitoring Techniques During Bridge Construction-phase. The Tajo River Viaduct Experience
}

Álvaro Gaute-Alonso ( $\sim$ gautea@unican.es )

University of Cantabria

David Garcia-Sanchez

Tecnalia

Carlos Alonso Cobo

University of Cantabria

Iñigo Calderon-Uriszar-Aldaca

University of Navarra

\section{Research Article}

Keywords: Structural monitoring systems, Load cells, Vibrating wire technique, Unidirectional strain gauges, Unidirectional accelerometers, Cable force

Posted Date: November 29th, 2021

DOI: https://doi.org/10.21203/rs.3.rs-1110581/v1

License: (9) (1) This work is licensed under a Creative Commons Attribution 4.0 International License. Read Full License 


\section{Temporary cable force monitoring techniques during the bridge}

\section{construction phase. The Tajo River Viaduct Experience}

Alvaro Gaute Alonso, PhD. Eng. (Corresponding author; alvaro.gaute@unican.es; ORCID: https://orcid.org/0000-0002-6195-7397; Grupo de Instrumentación y Análisis Dinámico de Estructuras, University of Cantabria); David Garcia-Sanchez, PhD. Eng. (david.garciasanchez@tecnalia.com; ORCID: https://orcid.org/0000-0002-4763-206X; TECNALIA Basque Research and Technology Alliance (BRTA)); Carlos Alonso Cobo, PhD ( Structural and Mechanical Engineering Area, University of Cantabria); and Iñigo Calderon-Uriszar-Aldaca, $\quad \mathrm{PhD}$ Eng (inigo.calderon@tecnalia.com; ORCID: https://orcid.org/0000-0002-6911-161X; University of Navarra; TECNALIA Basque Research and Technology Alliance (BRTA))

\footnotetext{
Abstract

This article addresses the comparative analysis of current techniques for monitoring cable forces. Additionally, the experience of three cable force different monitoring techniques for strain control in bridge cables during the construction phase is included: a) installing load cells on the active anchorages of the cables, b) installing unidirectional strain gauges, and c) assessing the stress on cables by applying the vibrating wire technique through the installation of accelerometers. The main advantages and disadvantages of each technique analyzed are highlighted in the construction process context of the Tajo Viaduct, one of the most singular viaducts recently built in Spain.
} 


\section{Keywords}

Structural monitoring systems; Load cells; Vibrating wire technique; Unidirectional strain gauges; Unidirectional accelerometers; Cable force.

\section{Introduction}

One of the solutions proposed by civil engineers to overcome large spans is to employ cable-stayed or hanging structures. The critical component of these structures lies in the vulnerability of the cables to problems or damage associated with fatigue and/or corrosion ${ }^{1}$ caused by dynamic loads such as cyclic traffic loads, wind loads, and other operational loads as well as environmental effects. Temporary suspension cables for the constructive phase present the same problems, and it is at this phase where the paper aims to impact.

The most important parameter for the assessment of stress and fatigue and corrosion damage to cables in service is the historical record of the axial effort over time of these structural elements. This parameter has been recognized as a useful feature damage indicator of the safety condition of stay and suspension cables in bridges ${ }^{2}$, and the realtime monitoring of this indicator has become essential for the assessment of potential fatigue damage in these structural elements. Nevertheless, the monitoring and evaluation of structural behavior has become standard practice to ensure the safety and durability of cable-stayed or suspended structures ${ }^{3-6}$. 


\section{Assessing safety conditions of construction cables}

Several nondestructive tests are used to diagnose the safety conditions of stay cables in bridges $^{6}$, such as ultrasonic testing, the magnetic flux leakage detection technique ${ }^{7}$, or X-rays. Although effective, these techniques are more suitable for the evaluation of outof-service stay cables.

On the one hand, various devices have been developed for the direct measurement of stress in bridge cables, such as load cells ${ }^{8-12}$, fiber Bragg grating optical sensors ${ }^{13}$, or elastomagnetic stress sensors ${ }^{14,15}$.

These sensors are capable, thanks to their specific technologies, of accurately determining the stress experienced by the cable, and when connected to a structural monitoring system (SMS), it is possible to create a long-term historical record of cable stresses and access these data in real time from any remote location.

On the other hand, a common indirect methodology for quick stress assessment in bridge cables is the vibrating wire technique. This method is based on the relationship between cable stress and its vibration frequency, which can be correctly identified from the recording of accelerations during free vibration of suspension cables ${ }^{16-21}$. For the application of this method, it is necessary to use spectral decomposition techniques that allow for a real-time determination of the stress on the suspension cables in bridges via the identification of vibration frequencies associated with their main vibration modes during a free vibration regime ${ }^{22-28}$.

\section{Direct and indirect monitoring technologies}

Many types of sensors and suppliers exist for each of the measuring techniques ${ }^{29-32}$. 


\subsection{Electronic and microelectromechanical system sensors (MEMSs)}

Electronic sensors transform the measurement (parameter to be measured) into a change in voltage, current, resistance, capacity or inductance. Electrical sensors come in many varieties and are usually very simple to interface to any datalogger system. Examples include potentiometer displacement sensors, resistive strain gauges, load cells, MEMS ${ }^{33}$ tiltmeters and piezo pressure sensors. Electrical sensors tend to be relatively inexpensive but can suffer from drift and can be affected or damaged by electromagnetic disturbances such as power lines of lightning.

\subsection{Vibrating wire}

Vibrating wire (VW) sensors ${ }^{34}$ transform the measuring into a chance in the vibration frequency of a string. In the case of the VW strain sensor, a strain change results in the variation of the tension of a steel wire, while in the case of VW piezometers, the deformation of a membrane due to a water pressure change also induces a change of tension of the sensing wire. Once the wire is excited with an electromagnet, it becomes possible to accurately measure its vibration frequency. Frequency measurements are very accurate and stable, so those sensors have become a standard for long-term accurate measurement in geotechnics and structural monitoring.

\subsection{Optical fiber}

From many points of view, optical fiber sensors ${ }^{35}$ are ideal transducers for structural health monitoring. These sensors transform the quantities to be measured into a change in the propagation characteristic of the light traveling through the optical fiber. Being durable, stable and insensitive to external perturbations, they are especially useful for long-term health assessments of civil structures and geostructures. Many different 
optical fiber sensor technologies exist, including fiber Bragg gratings, SOFO interferometers, Fabry Perot interferometers and distributed Brillouin and Raman sensors, and offer a wide range of performances and suitability for different applications.

In the earliest $90 \mathrm{~s}$, optical fiber sensors made a significant entrance into the sensor industry and currently have a consolidated presence in the structural sensing industry ${ }^{36}$.

\subsection{Distributed sensing}

Distributed fiber sensors ${ }^{37,38}$ represent a change of paradigm in terms of monitoring and sensing. Distributed sensors are able to sense at any point along a single standard telecommunication optical fiber line, allowing the discrimination of different positions of the measured parameter along the fiber transferring strain and temperature ${ }^{39}$ from the structure to the fiber.

Distributed sensors are particularly recommended ${ }^{40}$ to detect and discriminate events at any location within or among a structure.

\subsection{Optical/radar/laser}

These techniques are especially useful to monitor global movements of structures ${ }^{41}$. They include traditional geodesy methods, total stations with or without target prisms installed on the structure, laser distance meters and laser profilometers as well as terrestrial radars (including synthetic aperture radar). These techniques can be used, for example, to measure the deformation of a bridge, the movement of a tower, the progression of a landslide or the deflection of a dam. 


\subsection{Image based techniques}

Olaszek $^{42}$ developed a method that incorporated the photogrammetric principle with the computer vision technique to investigate the slow dynamic characteristics of bridges.

Patsias and Staszewski ${ }^{42}$ and Yoshida et al. $^{44}$ started the use of videogrammetric techniques to measure the mode shapes of a beam and to capture the $3 \mathrm{D}$ dynamic behavior of different structures. Chung et al. ${ }^{45}$ used digital image techniques to identify nonlinear characteristics in more complex structural systems. Chang and $\mathrm{Ji}^{46}$ developed a two-camera videogrammetric technique for measuring a $3 \mathrm{D}$ structural vibration response at the laboratory level. $\mathrm{In}^{47}$, $\mathrm{Ji}$ and Chang proposed a novel nontarget technique based on image analysis using one digital camera for cable vibration measurement, but again, it is a proof-of-concept.

These techniques, although promising and most of them verified at the laboratory level or under controlled conditions, do not seem to provide complete dynamic information, only partial to free vibration. That is why application during construction needs to wait for a more advanced development level.

\section{Application in the Construction Process of the Tajo River Viaduct}

\subsection{General Tajo River Viaduct description}

The Tajo River Viaduct belongs to the Madrid-Extremadura high-speed rail. It is located in the province of Caceres and has a total length of $1,488 \mathrm{~m}$. Its span distribution is determined by the width of the Tajo River, over which the arched viaduct spans $324 \mathrm{~m}$. The above deck is divided into six spans of $54 \mathrm{~m}$ each. The access spans are $60 \mathrm{~m}$ long, with two $57 \mathrm{~m}$ transition spans between these and the deck spans above 
the arch, one on each springer. This results in a suitable and harmonious distribution of the 26 spans that compose the deck of the Tajo River Viaduct: $45 m+9 x 60 m+57 m+$ $6 x 54 m+57 m+7 \times 60 m+45 m^{48,49}$.

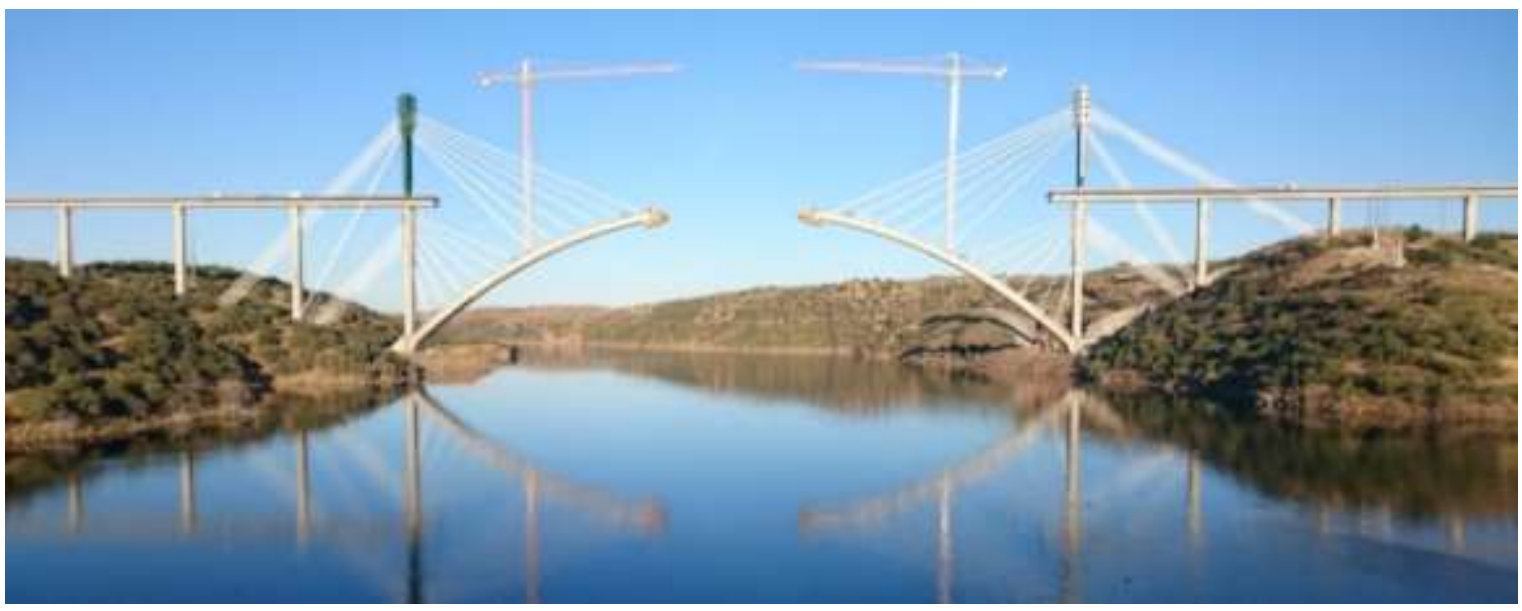

Figure 1. Tajo River Viaduct during its construction.

The layout of the viaduct first presents a very wide curve and then a straight line throughout the rest of the bridge. The most emblematic element of this viaduct is the arch, with a span of $324 \mathrm{~m}$ between its supports, rising above its foundations to a height of $70 \mathrm{~m}$ and above the maximum level of the Alcántara Reservoir to a height of over 80 m. The arch is formed by a box section that varies in edge and width, with an edge height of $4 \mathrm{~m}$ and a width of $12 \mathrm{~m}$ at the springers and an edge of $3.50 \mathrm{~m}$ and a width of $6 \mathrm{~m}$ at the keystone section. The deck has a pretensioned, concrete box section with a constant edge of $3.60 \mathrm{~m}$ and a total width of $14 \mathrm{~m}$, thereby accommodating the doubletrack railway of $10.10 \mathrm{~m}$ width and two walkways of $1.75 \mathrm{~m}$ width on each side. The lower width of the box is $5 \mathrm{~m}$, the top width is $6.50 \mathrm{~m}$, and it has side overhangs that fill the total width of the cross-section up to $14 \mathrm{~m}$. The piers have a variable height to adapt to the profile of the layout, reaching heights of over $70 \mathrm{~m}$ in the area nearest to the springers of the arch-type main span. All the piers consist of a single shaft with a hollow 
box section, except for their heads, where the section is solid to receive the loads transmitted by the deck.

\subsection{Construction Process}

The construction of the arch was carried out using the technique of successive, cablestayed overhangs by means of two temporary towers located on the piers at the springers of the arch on both banks of the river (see Fig. 1). Each tower was cablestayed to the foundations of the neighboring piers, which is why it was necessary to provide these foundations with ground-anchoring prestressed units. For the construction phase of the arch, fifteen pairs of cables held each complete half arch, and another fifteen pairs held the tower. The length of these cables ranged from 80 to $180 \mathrm{~m}$.

Each half arch is composed of a total of 46 voussoirs, each of $4 \mathrm{~m}$ length. It was necessary to place a keystone to complete and close the arch. The concrete trolley is a metal element that supports the formwork of each voussoir and its concrete. This trolley was located in the area of the arch that had been most recently concreted to prepare the concrete of the next voussoir.

Once the arch was finished, the temporary cable system consisting of the temporary towers, cables and ground anchors was dismantled. At this point, two adjacent piers on each side of the arch were built; these, together with the keystone, support the deck above the arch. The construction of the deck was carried out span by span by means of a self-supporting formwork arranged from both abutments. To avoid the creation of excessive stresses on the arch, the deck was symmetrically concreted, and a maximum offset of a single span was admitted. 


\subsection{Analysis of cable monitoring methodologies during bridge construction processes}

During the structural monitoring of the Tajo River Viaduct, three methodologies were used to monitor the stress in the temporary suspension cables of the arch-type main span: (a) strain gauge load cells arranged at the active anchorage of the temporary cables, (b) unidirectional strain gauges installed on one of the seven wires belonging to one of the strands in the cable, and (c) instrumentation of the cable by means of a unidirectional accelerometer.

\subsubsection{Direct monitoring of cables with strain gauge load cells}

The strain gauge load cells designed by the authors for the instrumentation of the temporary cables of the Tajo River Viaduct were composed of a metal ring arranged between the cable anchorage plate and the distribution plate in the pile or temporary tower. Due to the dimensions of the suspension cables, the average diameter of the load cells of the Tajo River Viaduct varied from $200 \mathrm{~mm}$ for the lowest loaded cables $(2,000$ $\mathrm{kN}$ ) to $500 \mathrm{~mm}$ for the highest loaded cables $(5,500 \mathrm{kN})$ (see fig 2).

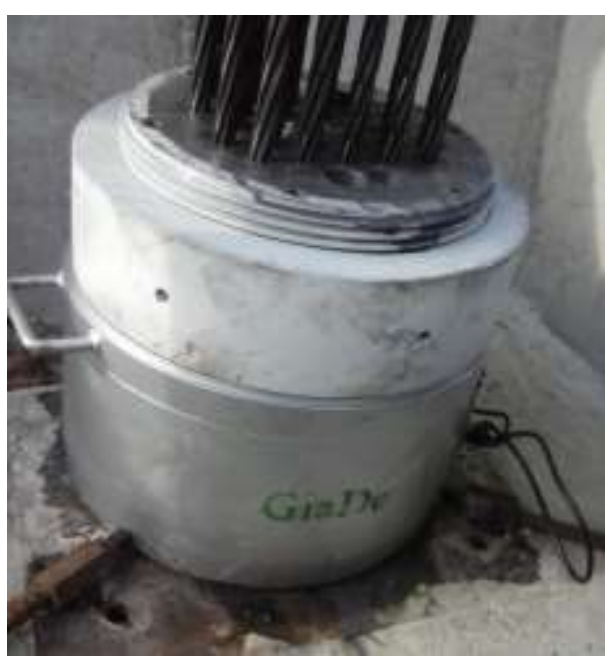

(a)

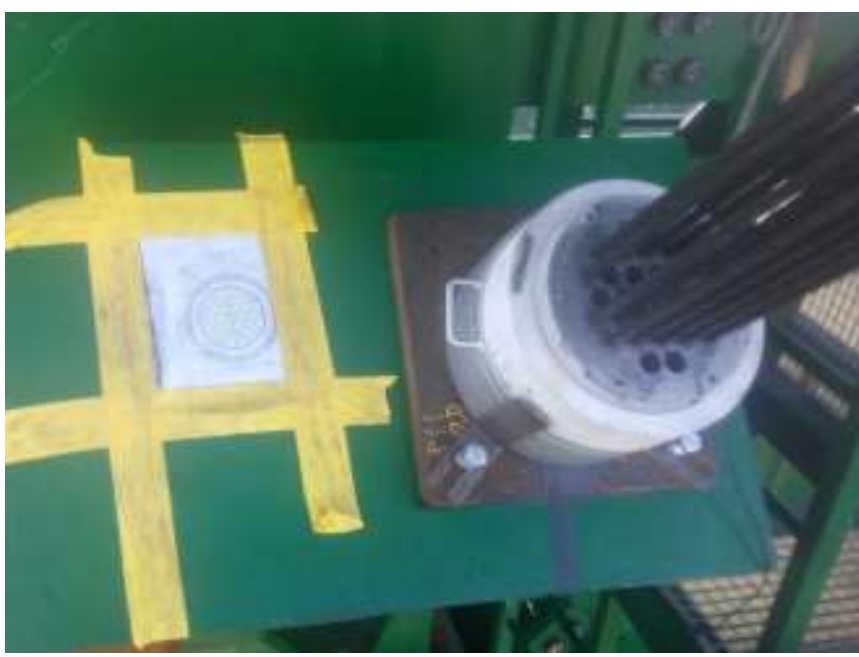

(b)

Figure 2. Tajo river viaduct load cells: a) pile load cell; b) load cell in temporary stay tower. 
This technology allows for the determination of the stress in the stay cable from the empirical characterization of the average normal strain in the central ring of the load cell; see eq. (1). To do this, the outer perimeter of the central ring is instrumented by the uniform distribution of bidirectional strain gauges connected in series by a full Wheatstone bridge configuration ${ }^{50,51}$.

$F=\oiint \sigma \cdot d \Omega=\frac{\sum_{1}^{n} \varepsilon_{i}}{n} \cdot E_{a} \cdot \Omega_{c}$

where $F=$ stress in the suspension cable; $\sigma=$ normal stress; $d \Omega=$ differential area at the central ring; $\varepsilon_{\mathrm{i}}=$ normal strain at the $\mathrm{i}^{\text {th }}$ strain gauge; $\mathrm{n}=$ number of strain gauges; $\mathrm{E}_{\mathrm{a}}=$ modulus of elasticity of steel; $\Omega_{\mathrm{c}}=$ area of the central ring.

The load cells installed on the cables allowed us to certify the correct tensioning of the cable families and to characterize, in real time, the variations in the stress experienced by the suspension cables during the different phases of the construction process (see Fig. 3). These devices allowed for the detection of any of the following structural phenomena occurring during the construction process: (1) the variation of stress in the cable due to the daily thermal increase, with stress increments of approximately $150 \mathrm{kN}$ for daily temperature variations of $30 \mathrm{~K}\left(30^{\circ} \mathrm{C}\right)$; (2) the variation of stress due to the concreting of successive voussoirs, with stress variations that could range from 200/300 $\mathrm{kN}$ in the cables closest to the concreted voussoir, to values below the daily variation in the furthest cables; (3) the stress increments due to the tensioning of the successive families of cables (see Fig. 4), with stress variations above $500 \mathrm{kN}$ in the families closest to the cables placed under load, and below the daily load variation in the furthest families; or (4) the stress variations due to the load readjustment operations in cables. 


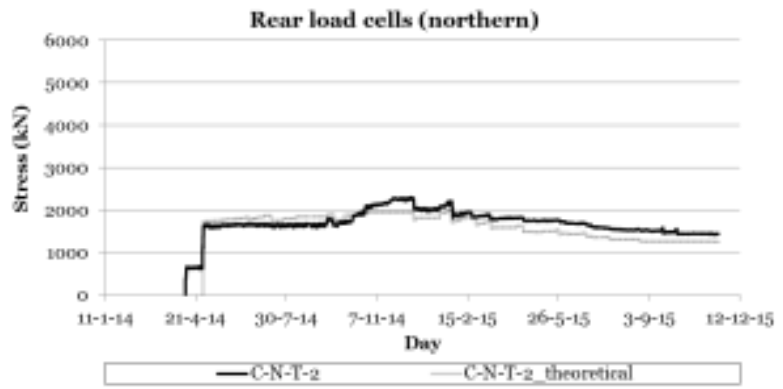

(a)

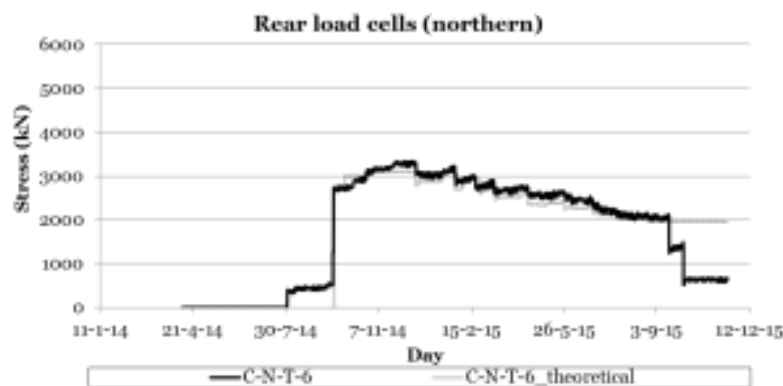

(c)

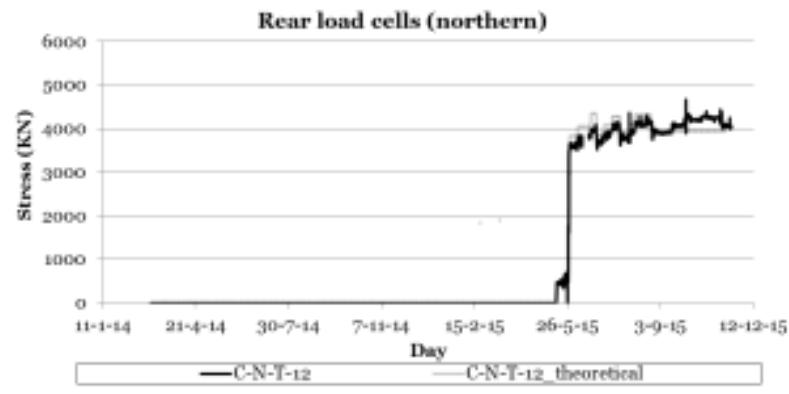

(e)

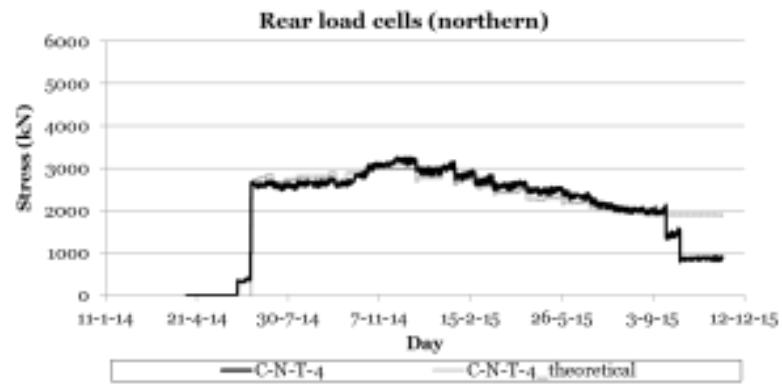

(b)

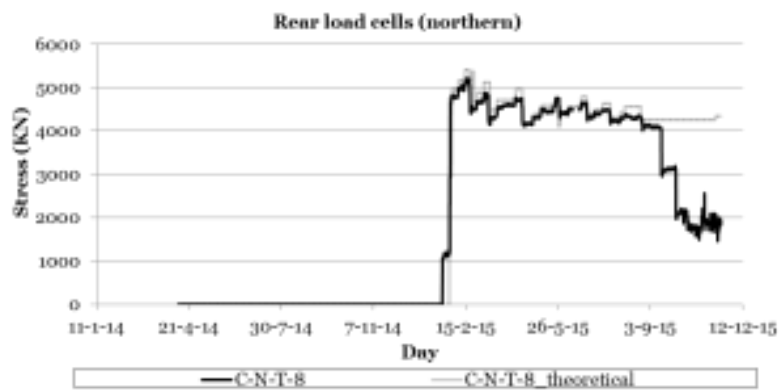

(d)

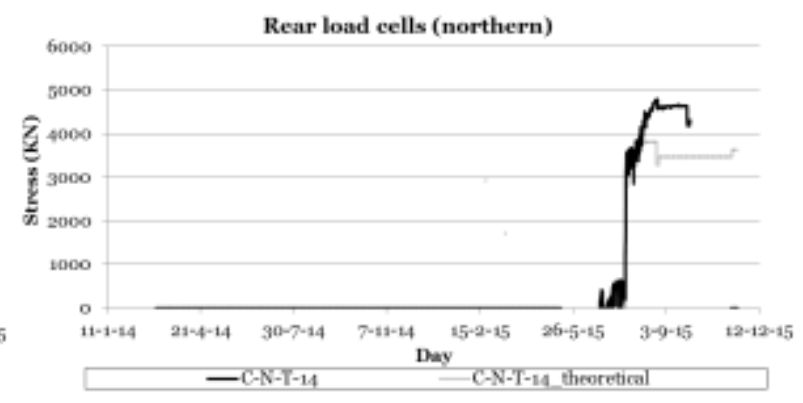

(f)

Figure 3. Evolution of stress on the cables of the rear load cells of the northern half arch: (a) $2^{\text {nd }}$ family of cables; (b) $4^{\text {th }}$ family of cables; (c) $6^{\text {th }}$ family of cables; (d) $8^{\text {th }}$ family of cables; (e) $12^{\text {th }}$ family of cables; (f) $14^{\text {th }}$ family of cables

Fig. 4 shows the evolution of the stress experienced by the tie rods of the eighth family. This graph shows the evolution of the effort characterized by the load cell installed on one of the rear tie rods, as well as the evolution of the theoretical effort predicted by the theoretical calculation model. The evolution of the experimented stress in the provisional tie-rods of the eighth family can be clearly appreciated, caused by the concreting of successive segments of the arch and by the tensioning of the successive tie-rod families. 


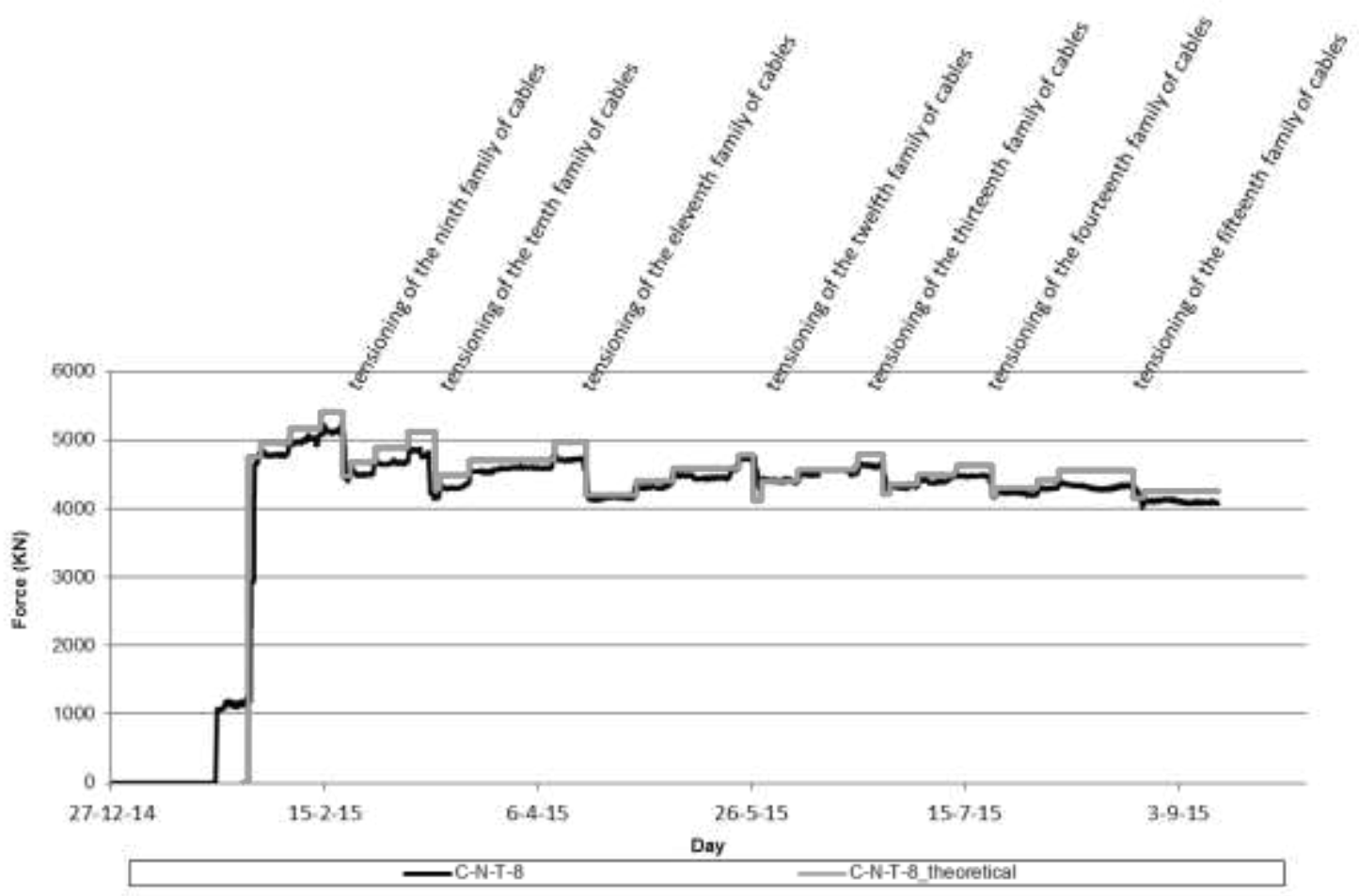

Figure 4. Evolution of the effort experienced by the tie rods of the eighth family.
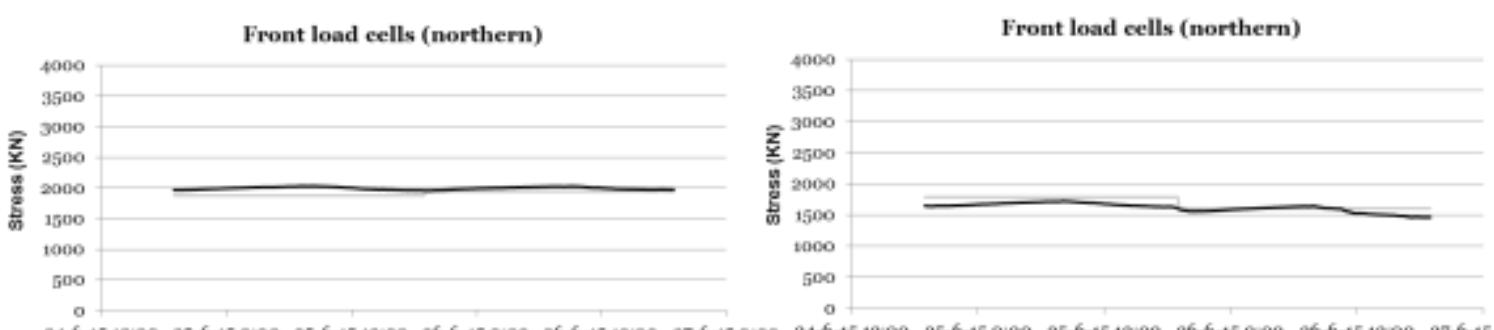

24-6-15 12:00 25-6-15000 25-6-15 1200 26-6-150:00 26-6-1512:00 27-6-15000 24-6-15 12-00 25-6-150:00 25-6-15 12:00 26-6-150-00 26-6-15 12-00 27-6-150:00

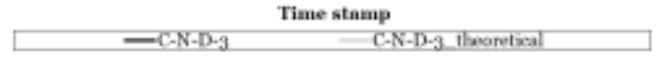

(a)

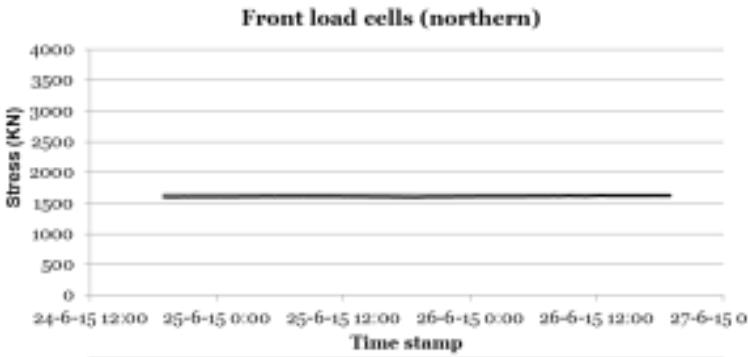

(c)

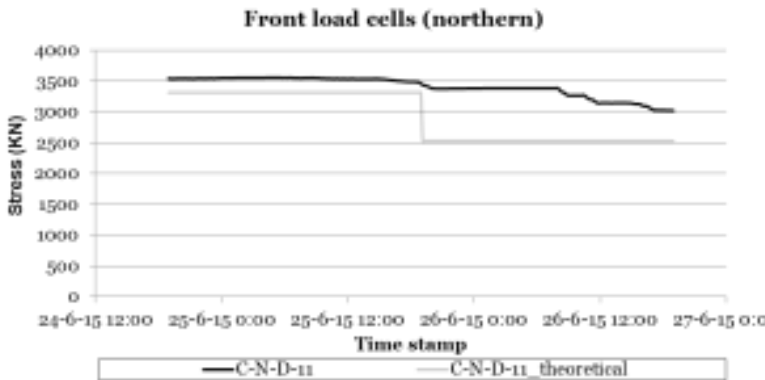

(e) (b)

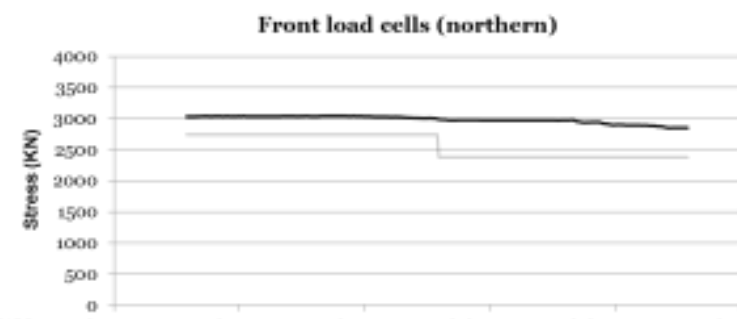

$24-6-151200 \quad 25-6-150: 00 \quad 25-6-15$ 12:00 26-6-150:00 26-6-15 12:00 27-6-150:00 Timae stamap

(d)

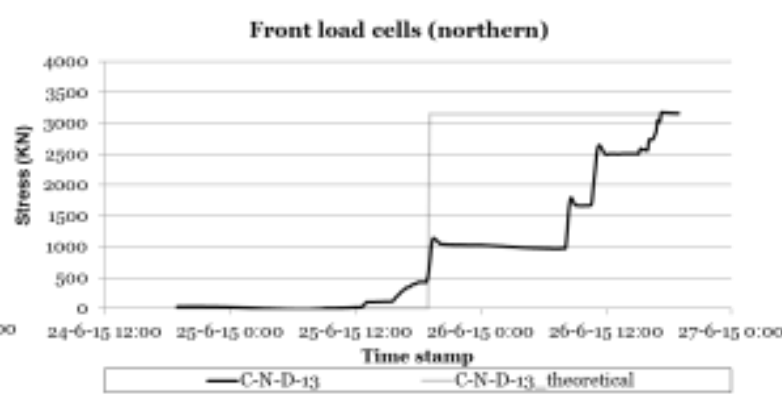

(f) 
Figure 5. Evolution of stress on the cables of the front load cells of the northern half arch during tensioning of the thirteenth family of cables: (a) 3rd family of cables; (b) 5th family of cables; (c) 7th family of cables; (d) 9th family of cables; (e) 11th family of cables; (f) 13th family of cables.

Fig. 3 shows the evolution of the stress experienced by the different families of retaining cables of the northern half arch and its comparison with the theoretical values of the project during all the construction phases of the arch-type main span, while Fig. 5 shows the evolution of the stress in the suspension cables of the northern half arch during the loading of the cables corresponding to the $13^{\text {th }}$ family of temporary cables.

\subsubsection{Direct monitoring of cables by installing unidirectional strain gauges on a wire from one of the strands in the temporary cable}

During the instrumentation of the cables corresponding to the first two families of temporary cables, the authors detected that the edge initially given to the strain gauge load cells was not sufficient to minimize the error induced by the irregularities in the boundary conditions. These sensors had to be complemented with other types of sensors that would allow the characterization of stress variations on the cables. Two unidirectional strain gauges were installed on one of the seven wires that compose one of the strands in the cable, connected to each other by a full Wheatstone bridge configuration $^{50,51}$. This technology allows for the instrumentation of cables once they are loaded and makes it possible to empirically characterize the stress increments experienced by the cable. 
The steel wires that compose the strand are twisted together so that the directrix of these wires has some angular deviation from the strand directrix (see Fig. 6). This fact makes the retrieval of the strand strain from the wire strain indirect and implies the need to perform the calibration of the measurement system in a tensile tester where the $\mathrm{kN} / \mu \varepsilon$ correlation between cable stress and wire strain can be obtained (see Fig. 7).

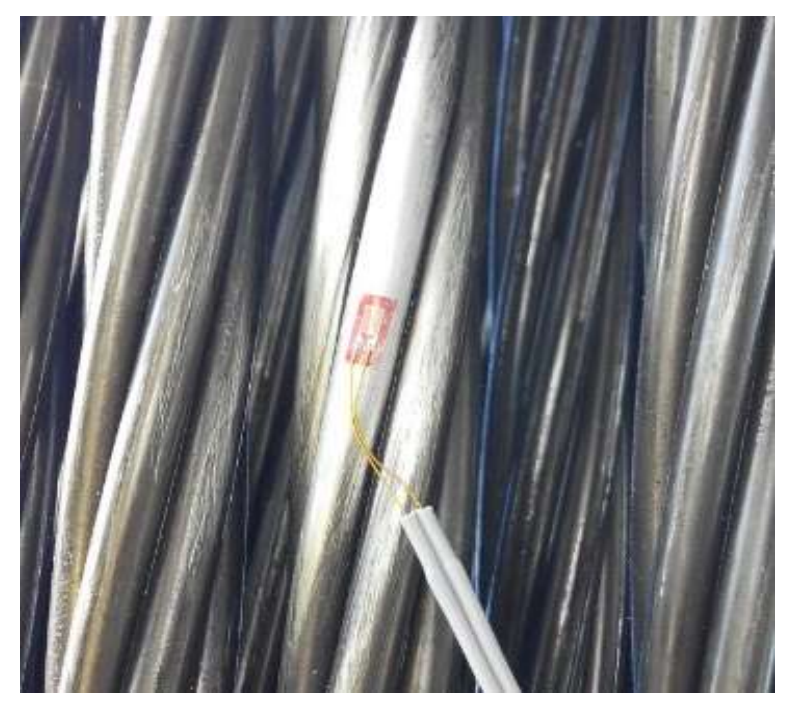

Figure 6. Installation of unidirectional strain gauges on one of the wires of a strand in a temporary cable 


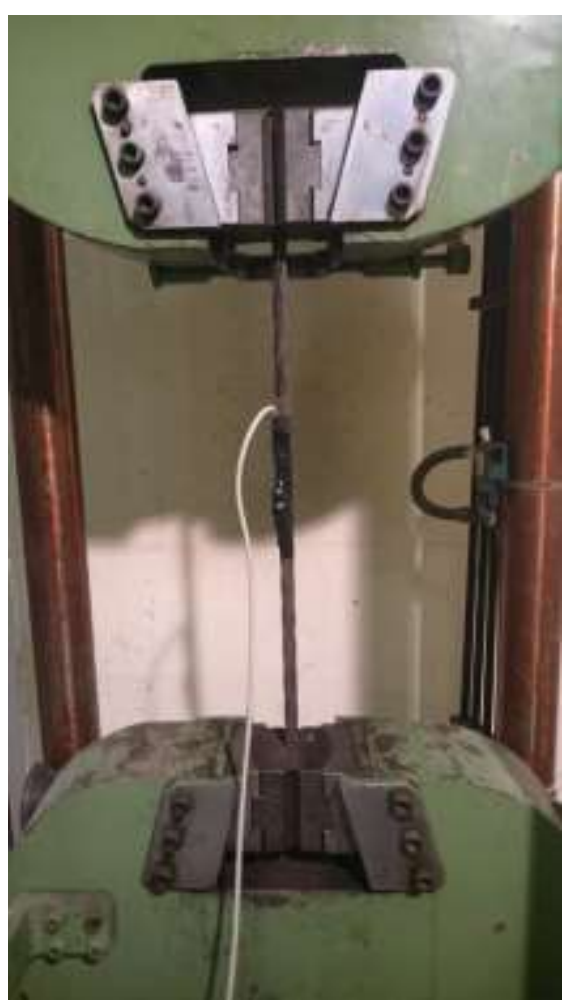

(a)

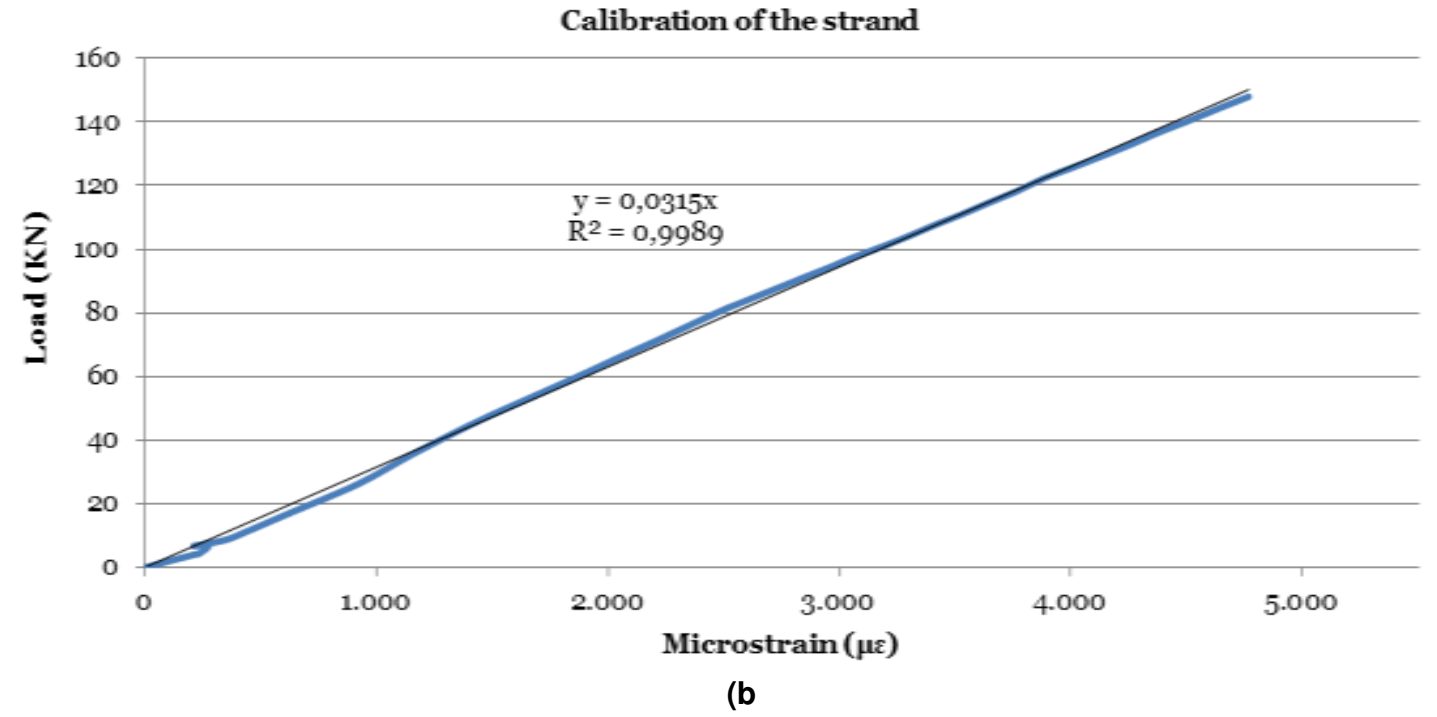

Figure 7. Calibration of the cable instrumentation method by the installation of unidirectional strain gauges: a) prestressing strand in load-bearing gantry; b) load/deflection curve during calibration test.

The simultaneous instrumentation of the first two families of tie rods by means of load cells and unidirectional extensometers installed in one of the strands that make up the 
tie facilitated a double contrast of the value of the stress experienced by these structural elements. Fig. 8 shows the evolution of the stress value in the intrumented tie rod of the fourth family of tie rods provided by the load cell (CNT-4), by the extensometers (CNT4_ext) and by the theoretical calculation model (CNT-4_theoretical). The graph shows the evolution of the stress in the instrumented tie rod due to the concrete of the successive segments of the arch and the tensioning of the successive families of temporary tie rods.

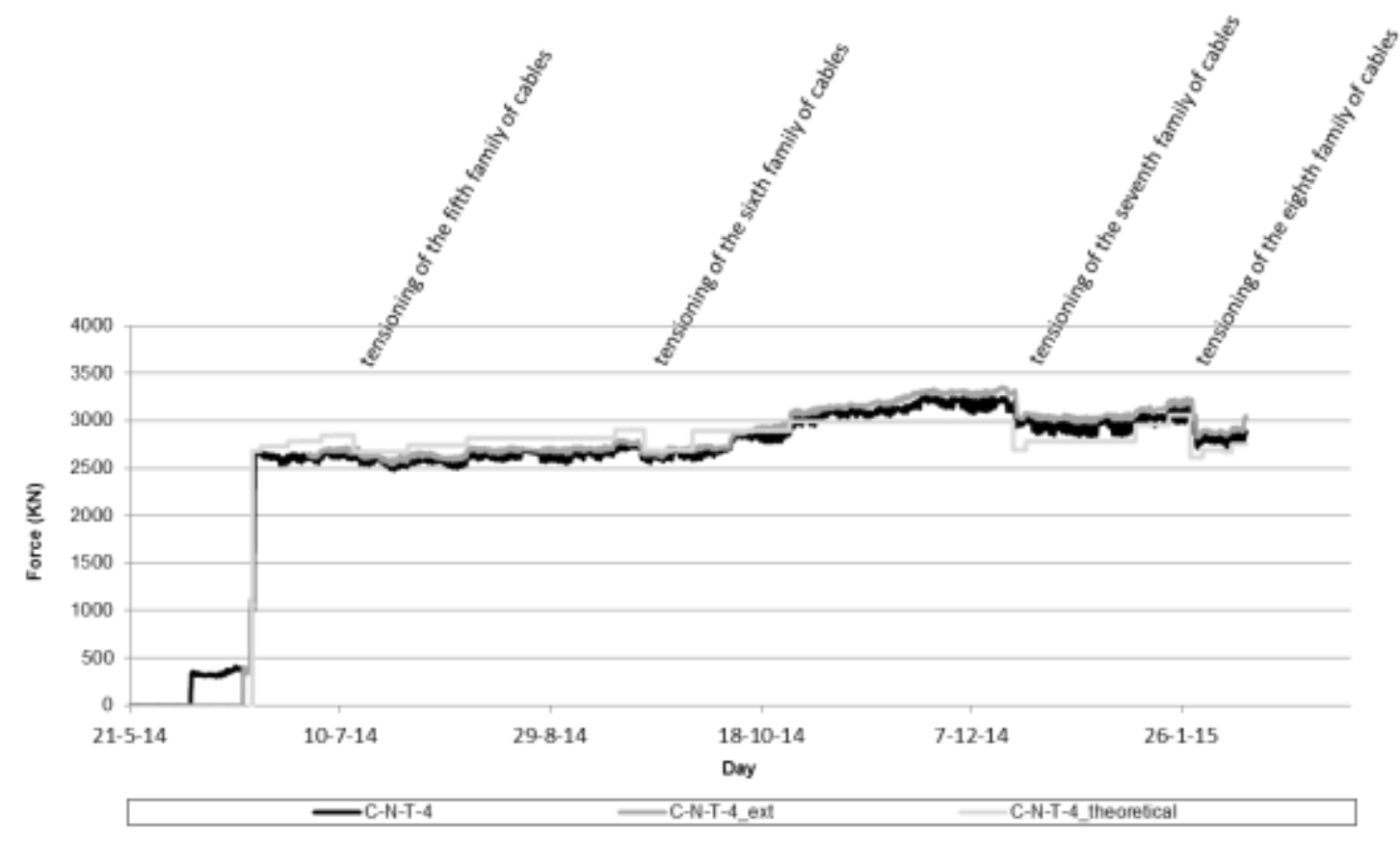

Figure 8. Evolution of the effort experienced by the tie rods of the fourth family.

\subsubsection{Indirect monitoring of cables with unidirectional accelerometers}

Due to the problems encountered in the measurements of the direct methodologies explained before arranged in the first two families of cables of the Tajo River Viaduct, the authors proposed carrying out a weighing campaign of the cables belonging to these families using the vibrating wire technique. This technique enables the measurement of the stress in bridge cables from the characterization of their vibration frequency and 
their mass ${ }^{16,52,53}$. The differential equation that relates the axial stress of a cable to its mass, its bending stiffness and its vibration frequency is as follows:

$E \cdot I \cdot \frac{\partial^{4} \vartheta(x, t)}{\partial x^{4}}-T \cdot \frac{\partial^{2} \vartheta(x, t)}{\partial x^{2}}+m \cdot \frac{\partial^{2} \vartheta(x, t)}{\partial t^{2}}=0$

The solution eq. (3) to the differential eq. (2) allows for the axial stress of the cable to be obtained.

$f=\frac{u}{2 \cdot L} \sqrt{\frac{T}{m}} \cdot\left[1+2 \cdot \sqrt{\frac{E \cdot I}{F \cdot L^{2}}}+\left(4+\frac{u^{2} \cdot \pi^{2}}{2}\right) \cdot \frac{E \cdot I}{F \cdot L^{2}}\right]$

The bending stiffness (E.I) in the bridge cables is negligible with respect to their axial stiffness. This fact makes the second and third sums of eq. (3) negligible with respect to the first, resulting in eq. (4), which relates the axial stress of the cable to its mass and oscillation frequency ${ }^{16}$. Fig. 9 shows the evolution of the error made, assuming the simplification set forth in eq. (4) for each of the families of temporary tie rods of the Tajo River Viaduct as a function of the stress experienced by these structural elements.

$f=\frac{u}{2 \cdot L} \cdot \sqrt{\frac{T}{m}}$

where $\mathrm{T}=$ Axial stress on the cable; $\mathrm{u}=$ Considered vibration mode; $\mathrm{f}=$ Vibration frequency corresponding to $\mathrm{u}$-mode; $\mathrm{E}=$ Modulus of elasticity of the material composing the cable; $\mathrm{I}=$ Moment of inertia of the cable; $\mathrm{L}=$ Vibration length of the cable; $\mathrm{m}=$ Mass per linear meter of the cable. 


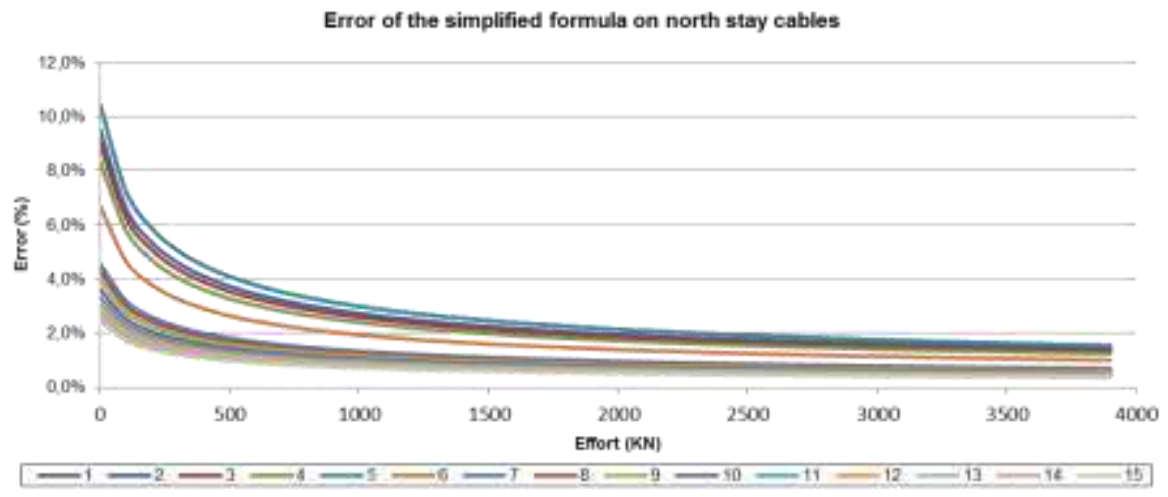

(a)

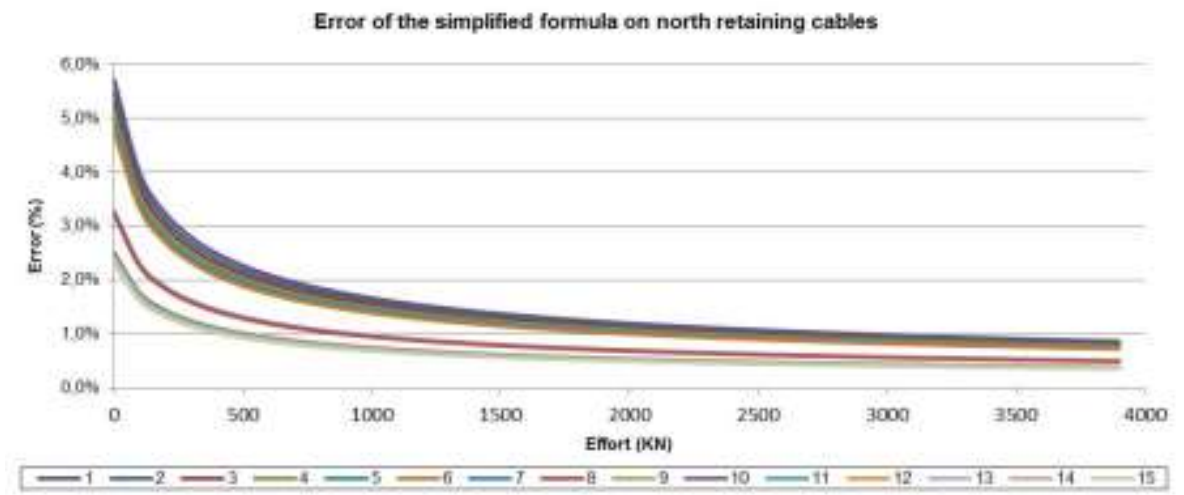

(b)

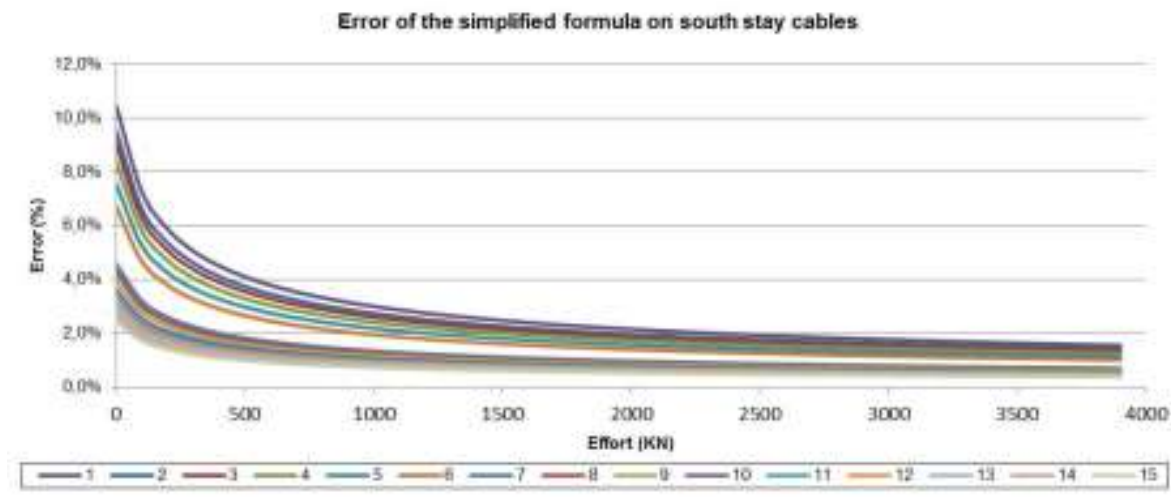

(c)

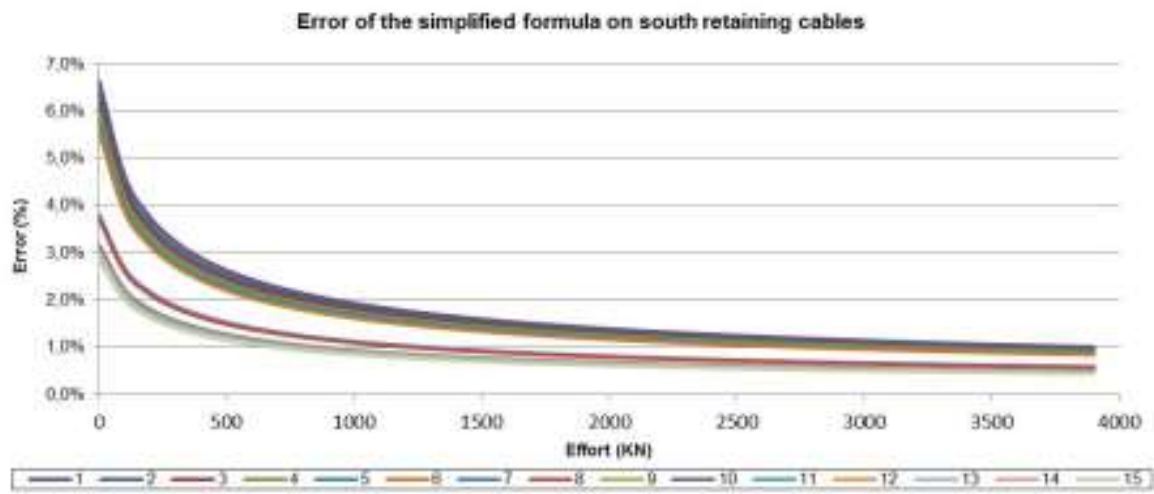

(d) 
Figure 9. Evolution of the error made by the simplified formulation of the vibrating wire: a) north stay cables; b) north retaining cables; c) south stay cables; d) south retaining cables.

To carry out the weighing of the cables by means of the application of the vibrating wire technique, a piezoelectric accelerometer was installed on the cable under testing through a tool that picks up the sheath-strand assembly, the cable was excited, and the accelerations experienced during its movement in free vibration were measured. To obtain the axial stress of the cable by applying eq. (4), it is necessary to take into account the total mass mobilized. In the case of the temporary cables of the Tajo River Viaduct, it was necessary to take into account the mass of the strands that composed the cable together with the mass of the protection sheath (see Fig. 10). The recordings of acceleration experienced by the cables were analyzed by applying the fast Fourier transform ${ }^{54-56}$, obtaining the eigenfrequencies of the cables and consequently their axial stress (see Fig. 11).

Because of prior experience with the construction of similar bridges ${ }^{5,55,57-59}$ where there were episodes of confluence between the frequency of generation of whirlwinds by the action of the wind on the structure and its frequency of vibration, the vibrating wire testing campaign was used to obtain the damping factor of the cables of the Tajo River Viaduct. Established to obtain the damping factor (see Fig. 12), the test consisted of subjecting the cable to an initial strain by applying a displacement in its main span and then releasing it abruptly, letting it oscillate in a free vibration regime. The damping factor of the cable is obtained from the logarithmic decrease between the maximum amplitudes of its oscillation during free vibrations; see eq. $(5)^{60}$ :

$$
\eta=\frac{c}{c_{c}}=\frac{1}{2 \cdot \pi \cdot n} \cdot \ln \left(\frac{A_{o}}{A_{n}}\right)
$$


where $\eta=$ damping factor with respect to the critical; $\mathrm{n}=$ number of cycles considered for the analysis; $\mathrm{A} 0=$ maximum amplitude in the initial oscillation considered for the analysis; and An = maximum amplitude in the nth oscillation considered for the analysis.

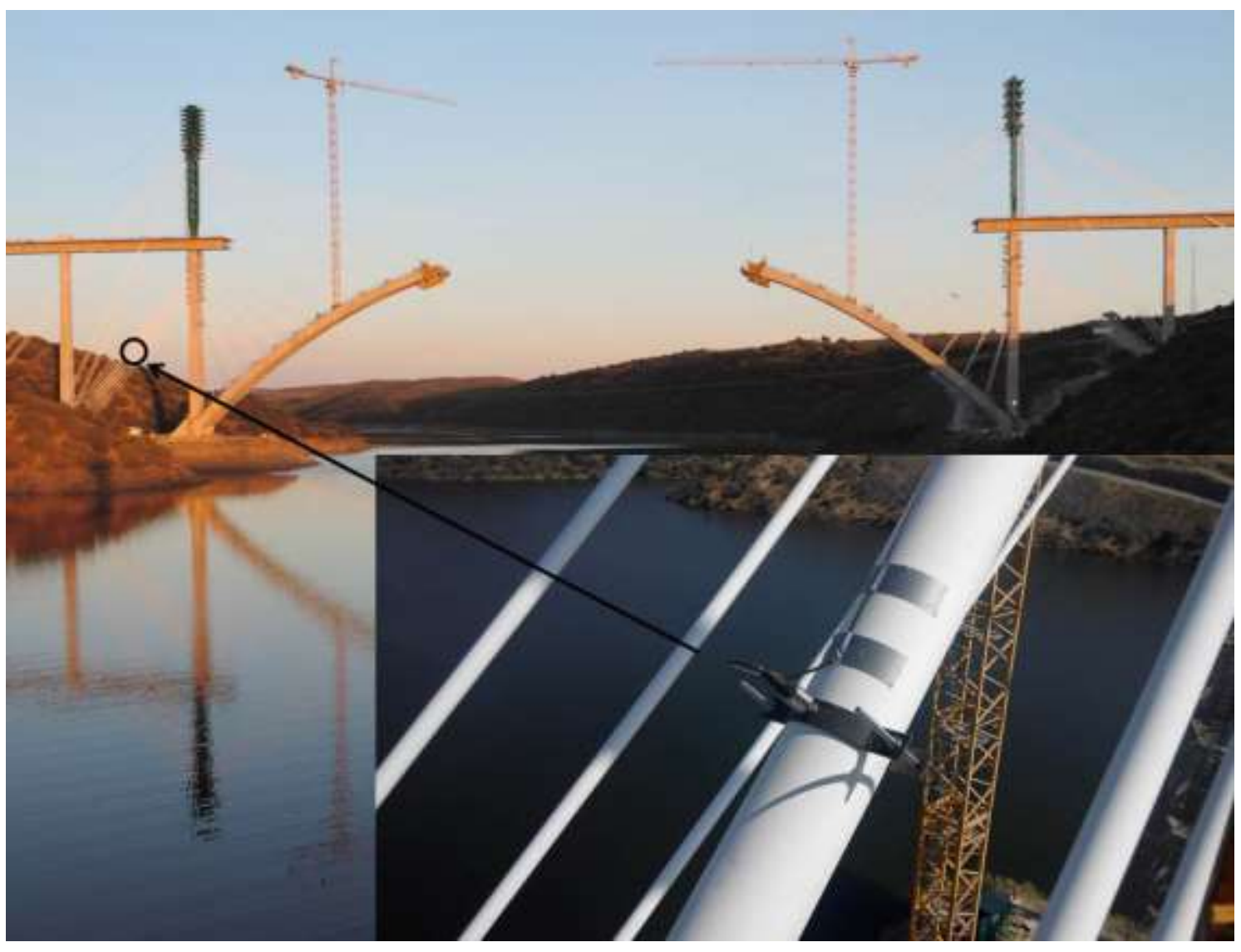

Figure 10. Piezoelectric accelerometer on the temporary tie of the Tajo Viaduct.

Looking for a twofold purpose, the authors proposed a solution that enabled the monitoring of the evolution of the stress in the cable and the characterization of the possible appearance of aeroelastic phenomena caused by resonance or similar phenomena ${ }^{5,55,57-59}$. This solution consisted of the permanent instrumentation of the right-hand retaining cable belonging to the fifth family of temporary cables of the northern half arch of the Tajo River Viaduct. To accomplish this, a piezoelectric accelerometer was installed on the selected cable using a tool identical to the one used 
in the vibrating wire spot testing campaign, and this sensor was connected to the SMS of the Tajo River Viaduct. Fig. 13 shows the monitoring of the evolution of stress in the cable obtained from the analysis of the data provided by the piezoelectric accelerometer.

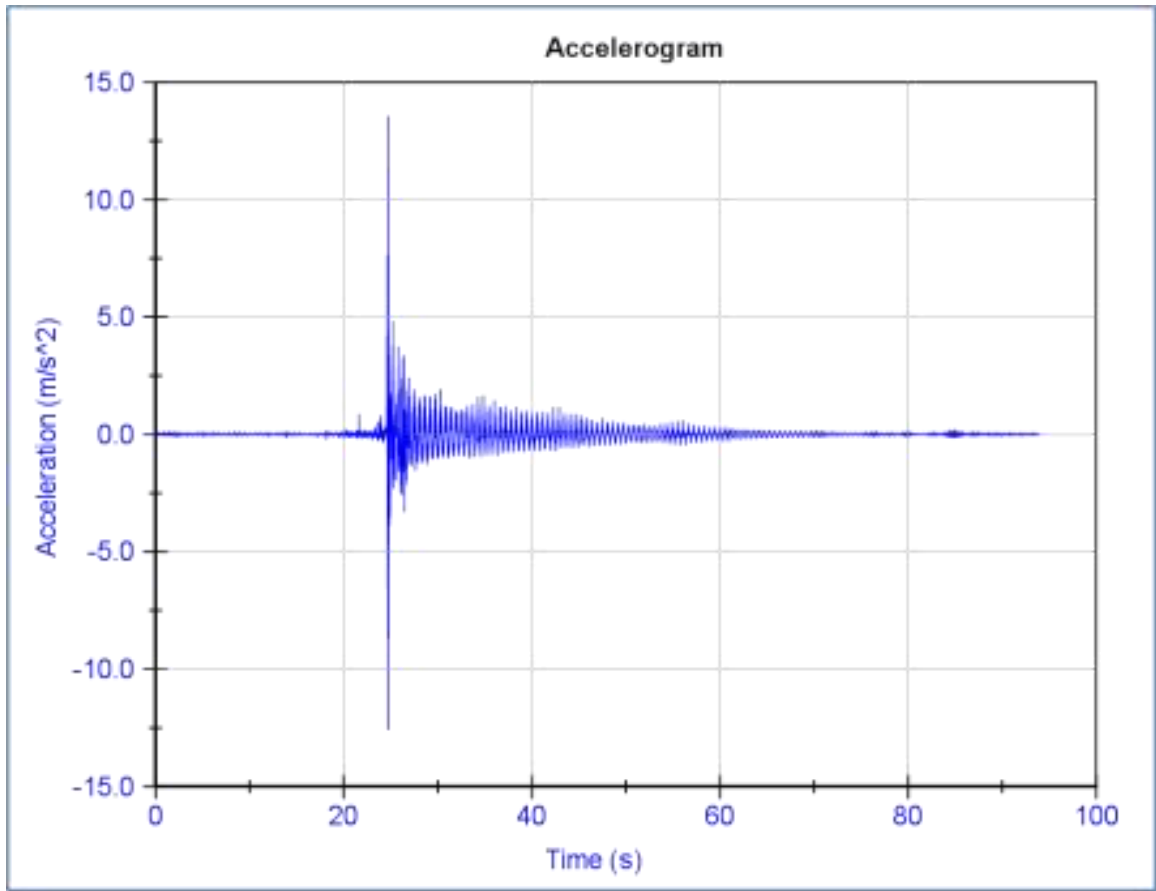

(a)

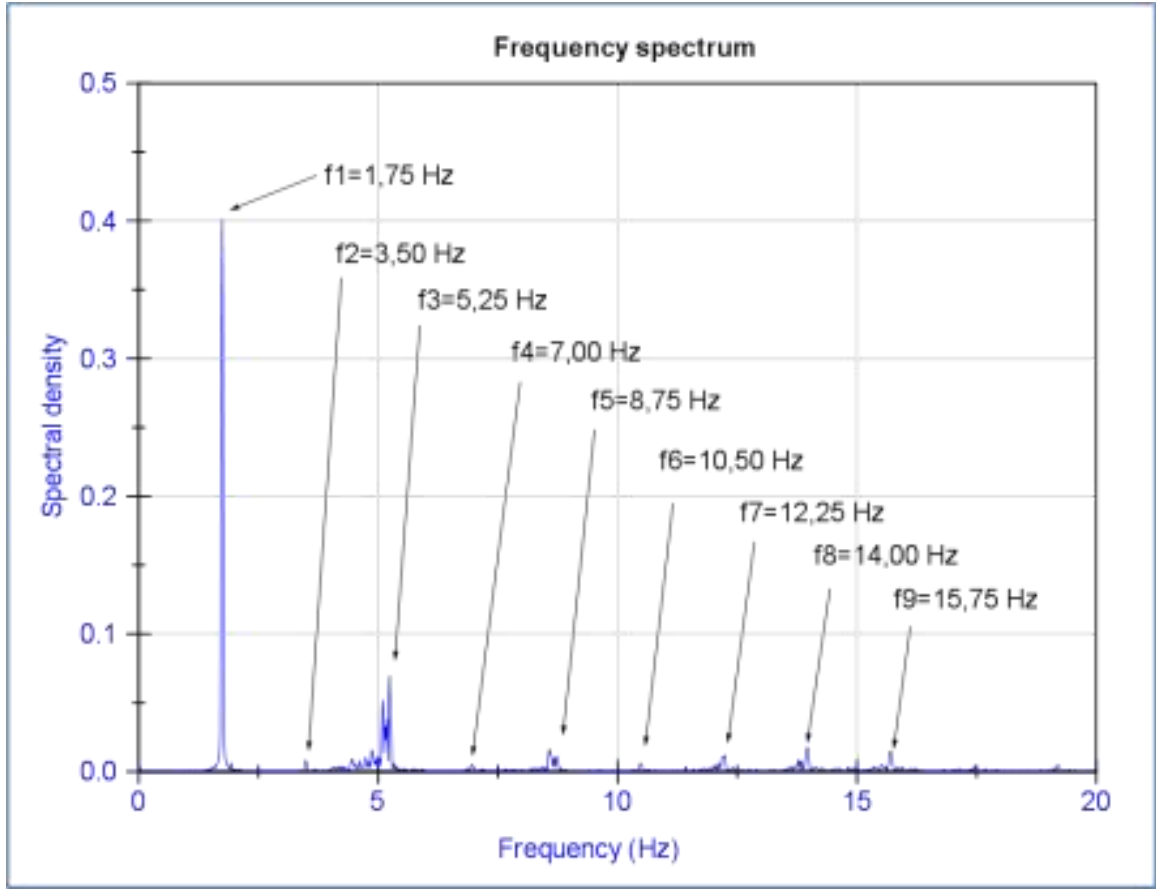

(b) 
Figure 11. Obtaining the stress in the fifth family of ties rod from their vibration frequencies: a) accelerogram; b) frequency spectrum.

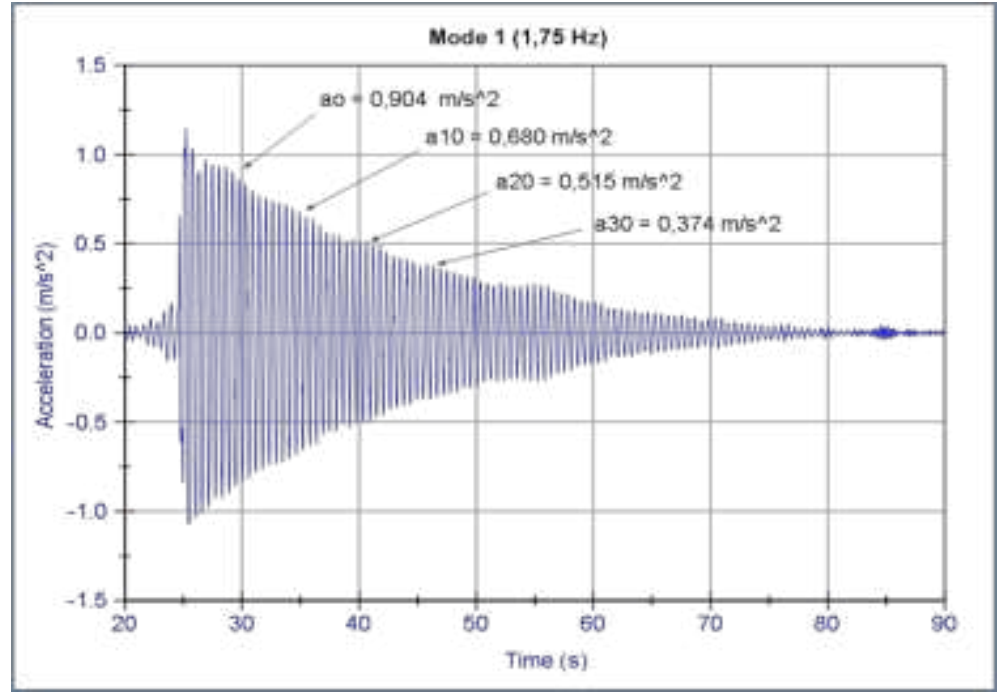

(a)

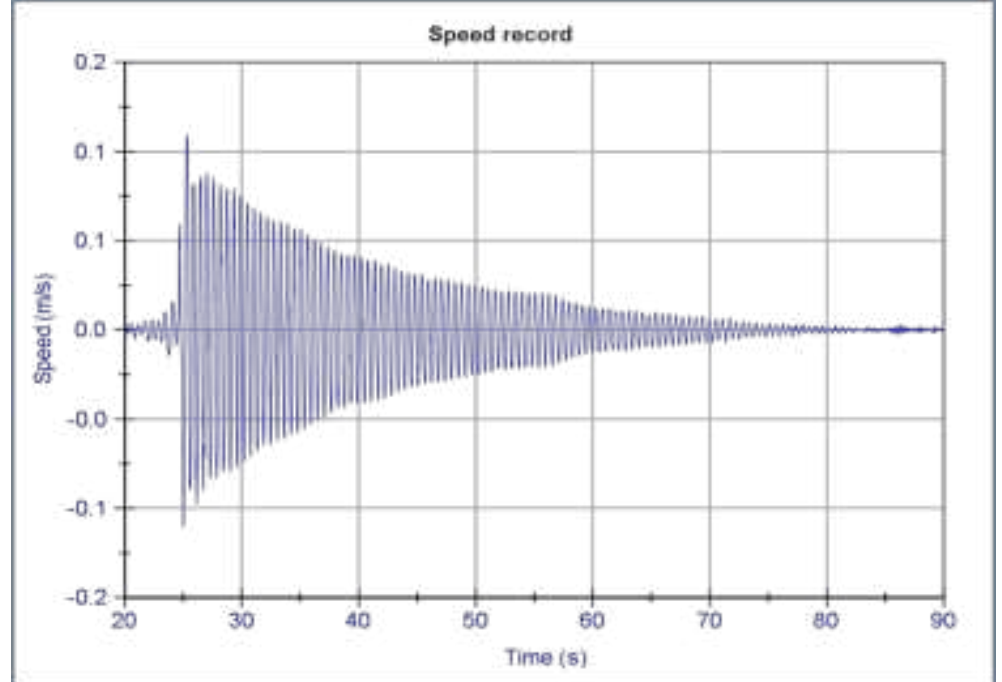

(b)

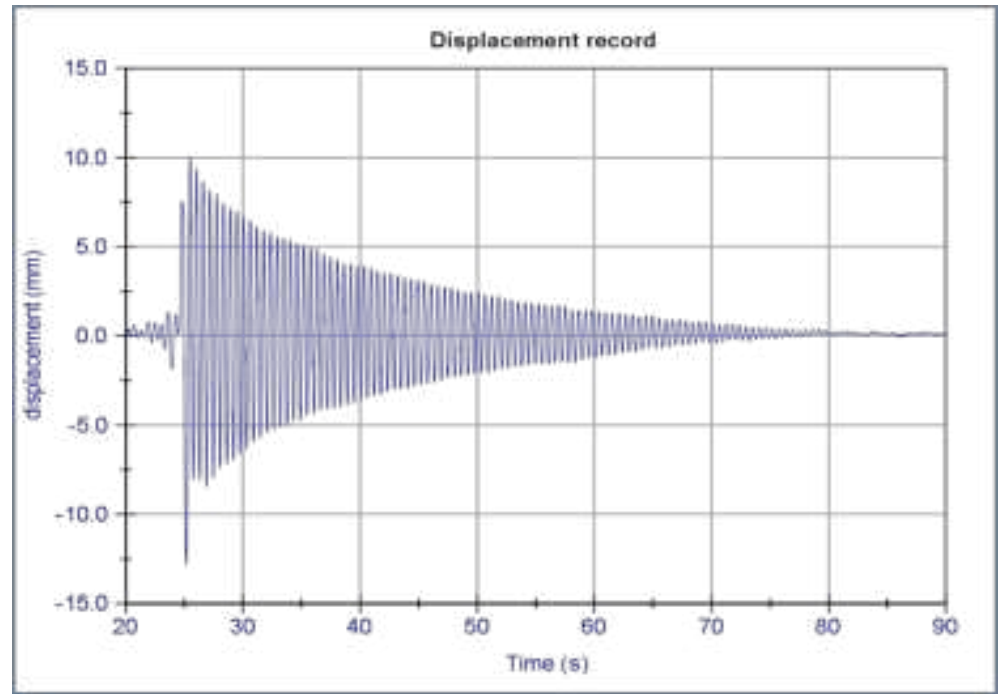

(c) 
Figure 12. Retrieval of the damping factor of the right-hand retaining cable of the fifth family of temporary cables of the northern half arch of the Tajo River Viaduct: a) recording of accelerations associated with the first mode of vibration; b) speed record; c) displacement record.

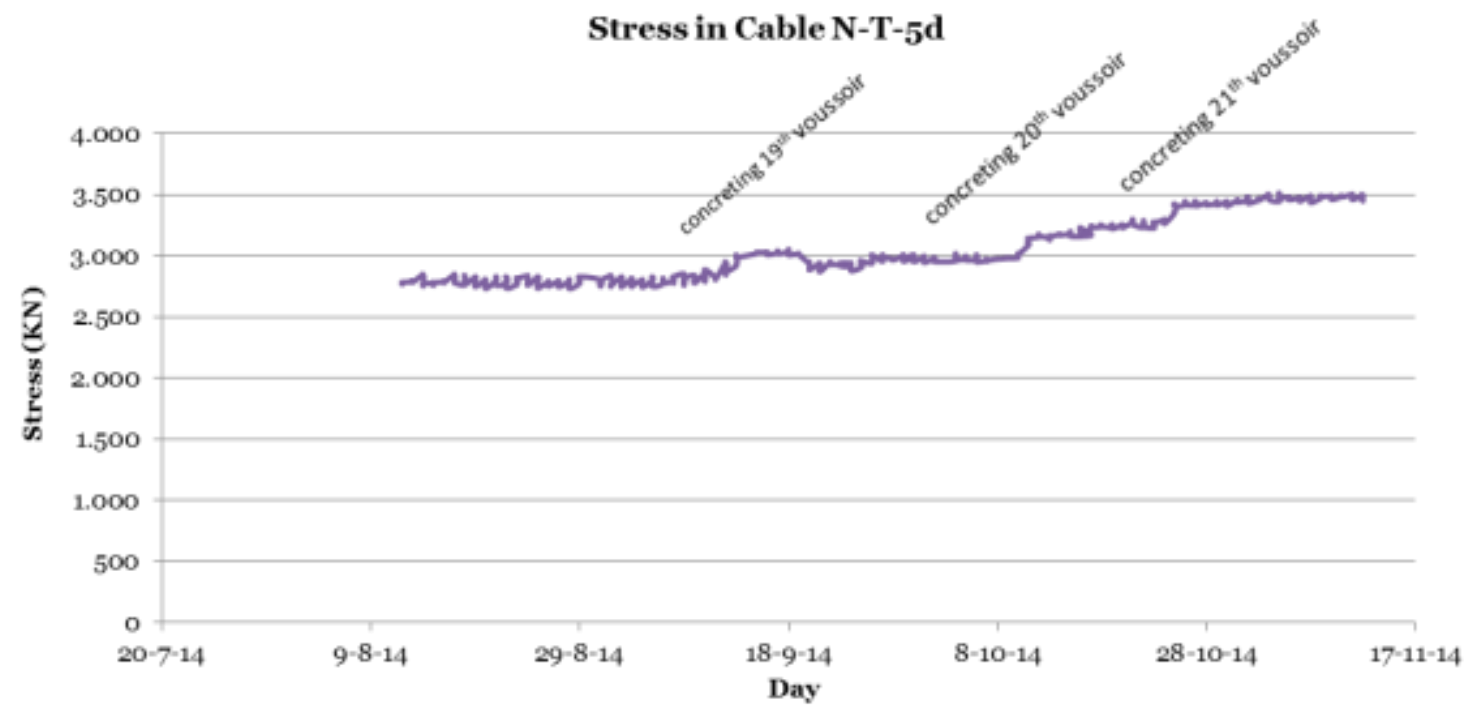

Figure 1. Monitoring of the evolution of the stress in the right-hand retaining cable belonging to the fifth family of temporary cables of the northern half arch of the Tajo River Viaduct using a piezoelectric accelerometer.

The simultaneous instrumentation of the first two families of tie rods using load cells and unidirectional strain gauges installed in one of the strands that make up the tie, together with the tie weighing campaign using the vibrating chord technique, allowed a comparative analysis of the effort facilitated for each of the structural monitoring techniques. Fig. 14 and Table 1 show the effort value provided by each of the structural monitoring techniques used by the authors. 


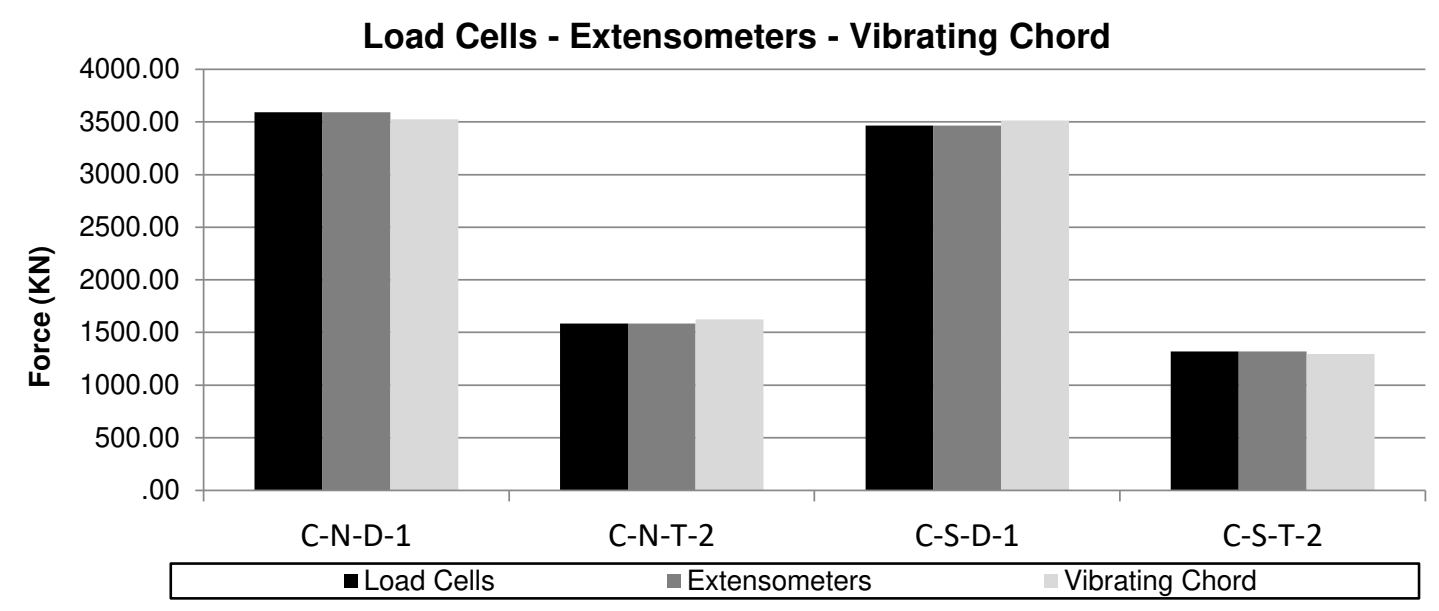

Figure 2. Effort facilitated by each of the structural monitoring techniques used.

\begin{tabular}{ccccc} 
& Time Stamp & Load Cell (KN) & $\begin{array}{c}\text { Extensometer } \\
(\text { KN) }\end{array}$ & $\begin{array}{c}\text { Vibration } \\
\text { Chord (KN) }\end{array}$ \\
\hline C-N-D-1 & $16 / 05 / 20149: 06$ & $3.501,4$ & $3.591,1$ & $3.525,0$ \\
C-N-T-2 & $16 / 05 / 201410: 36$ & $1.632,7$ & $1.586,4$ & $1.624,7$ \\
C-S-D-1 & $17 / 05 / 20149: 30$ & $3.493,0$ & $3.465,6$ & $3.511,2$ \\
C-S-T-2 & $17 / 05 / 201410: 10$ & $1.299,9$ & $1.319,6$ & $1.295,2$
\end{tabular}

Table 1. Effort facilitated by each of the structural monitoring techniques used.

\section{Lessons learned}

The lessons learned during Tajo's Viaduct monitoring thanks to the installation of the different sensor technologies are synthesized in Table 2 and can be summarized as follows:

$\underline{\text { Strain gauge load cells }}$

- Advantages:

- Allows measurement of the stress on the cables with an error lower than $1 \%$.

○ Robust, shock-resistant, and weather-resistant solutions.

- Disadvantages:

○ Entails the greatest economic investment. 
- The instrumentation of heavy-duty cables involves the design of large, very heavy load cells that are difficult to handle and install on-site.

O Installation is only possible prior to the cable installation operation.

\section{$\underline{\text { Unidirectional strain gauges }}$}

- Advantages:

○ Technique that entails the lowest economic investment.

O Installation is possible at any stage of the construction process.

- Disadvantages:

○ Least robust solution, very sensitive to shocks and weather.

o In the case of its installation, once in service, the cable provides the stress increments on the structural element, but it is not possible to obtain the absolute value of the stress on the cable.

- The accuracy of the measurement of stress on the cables is greatly influenced by the correct on-site installation of the device.

\section{$\underline{\text { Unidirectional accelerometers }}$}

- Advantages:

○ Installation is possible at any stage of the construction process.

Allows the recording of the absolute value of the stress on the cable regardless of the phase of the construction process in which the sensor has been installed.

- Allows measurement of the stress on the cables with an error lower than $1 \%$.

- Disadvantages:

- The technique generates a high volume of data, and it is necessary to resort to spectral decomposition techniques to obtain the stress on the cable.

$\begin{array}{ccc}\text { Cost } & \begin{array}{c}\text { Cost } \\ \text { sensor }\end{array} & \begin{array}{c}\text { Long-term } \\ \text { accuracy }\end{array}\end{array}$ Durability Density of info.




\begin{tabular}{cccccc} 
Load cells (D) & $\$ \$$ & $\$$ & Very Good & $\begin{array}{c}\text { Very } \\
\text { Good }\end{array}$ & Low \\
\hline $\begin{array}{c}\text { Electrical/MEM } \\
\text { S (D) }\end{array}$ & $\$$ & $\$ \$$ & Poor & Poor & Low \\
\hline $\begin{array}{c}\text { Vibrating Wire } \\
(\mathrm{I})\end{array}$ & $\$ \$$ & $\$ \$$ & Very Good & Medium & High
\end{tabular}

Table 23. Summary table for the validation of different tested technologies based on Tajo viaduct experience.

\section{Conclusions}

Thanks to this work, the authors intend to give an overview of the different monitoring systems currently used for temporary cable force monitoring techniques during the bridge construction phase. Therefore, a review of the state of the art has been conducted. An overview of load cells, unidirectional strain gauge systems and accelerometers is also provided. All these methods are well established and very accurate. Nonetheless, each of them has its own advantages and disadvantages regarding installation and implementation. The most promising technique currently under development is image-based techniques and can be considered complementary to these currently available methods. Today, this technique cannot provide the same level of accuracy as the current methods, but it is inexpensive and simple to use when compared to the accelerometer, i.e.. Further development is still needed before it can be implemented on long-span cable-stayed bridges because their behavior becomes nontrivial. In fact, a long-span bridge is susceptible to environmental and trafficinduced vibration.

Taking into account all these points, this article aims to serve as a base for all work related to the world of cable monitoring during bridge construction. 


\section{Data Availability Statement}

The data that support the findings of this study are available from the corresponding author, Gaute A., upon reasonable request.

\section{Acknowledgments}

The authors would like to thank "Administración de Infraestructuras Ferroviarias ADIF" (Administrator of Railway Infrastructures) for trusting the University of Cantabria's Structures Laboratory to carry out the structural monitoring of the Tajo River Viaduct.

This work has received funding from the European Union Horizon 2020 research and innovation program under grant agreement No 769373 (FORESEE project). This paper reflects only the author's views. The European Commission and INEA are not responsible for any use that may be made of the information contained therein.

\section{References}

1. H. Tabatai, Transportation Research Board, Inspection and Maintenance of Bridge Stay Cable Systems, National Cooperative Highway Research Program, 2005, Washington, D.C.

2. Y. Yang, S. Li, S. Nagarajaiah, H. Li and P. Zhou, Real-Time Output-Only Identification of Time-Varying Cable Tension from Accelerations via Complexity Pursuit, Journal of Structural Engineering, 2016, vol. 142, $\mathrm{n}^{\circ} 1$. https://doi.org/10.1061/(ASCE)ST.1943-541X.0001337.

3. Y. Q. Ni, K. Y. Wong and Y. Xia, Health Checks through Landmark Bridges to Sky-high Structures, Advances in Structural Engineering, 2011, vol. 14, p. 103-119. https://doi.org/10.1260/1369-4332.14.1.103.

4. S. Nagarajaiah and Y. Yang, Blind modal identification of output-only nonproportionally damped structures by time-frequency complex 
independent component analysis, Smart Structures and Systems, 2015, vol. 15, p. 81-97.

5. D. W. Olson, S. F. Wolf and J. M. Hook, The Tacoma Narrows Bridge collapse, Physics Today, 2015, vol. 68, $\mathrm{n}^{\circ}$ 11, p. 64-65. https://doi.org/10.1063/PT.3.2991.

6. A. B. Mehrabi, In-service evaluation of cable-stayed bridges, overview of available methods, and findings, Journal of Bridge Engineering, 2006, vol. 11, p. 716-724. https://doi.org/10.1061/(ASCE)1084-0702(2006)11:6(716).

7. F. Xu, X. Wang and H. Wu, Inspection method of cable-stayed bridge using magnetic flux leakage detection: principle, sensor design, and signal processing, 2012, vol. 26, $n^{\circ} 3, \quad$ p. 661-669. https://doi.org/10.1007/s12206-011-1234-x.

8. L. Caro, J. Martí-Vargas and P. Serna, Prestress losses evaluation in prestressed concrete prismatic specimens, Engineering Structures, 2013, vol. 48, p. 704-715. https://doi.org/10.1016/j.engstruct.2012.11.038.

9. A. Freddi, G. Olmi and L. Cristofolini, Introduction to the Application of Strain Gages, Experimental Stress Analysis for Materials and Structures, Springer International Publishing, 2015, p. 23-100.

10. T. Guo. Z. Chen. S. Lu and R. Yao, Monitoring and analysis of long-term prestress losses in posttensioned concrete beams, Measurement, 2018, vol. 122, p. 573-581. https://doi.org/10.1016/j.measurement.2017.07.057.

11. J. Martí-Vargas, L. Caro and P. Serna, Experimental Technique for Measuring the Long-term Transfer Length in Prestressed, Strain, 2013, vol. 49, n² 2, p. 125-134. https://doi.org/10.1111/str.12019.

12. R. Varatharajoo, E. J. Abdullah, D. L. Majid, F. I. Romli, A. S. M. Rafie and K. A. Ahmad, Load Cell Application in Rocket Thrust Measurement System, Applied Mechanics and Materials, 2012, vol. 225, p. 437-441. https://doi.org/10.4028/www.scientific.net/AMM.225.437.

13. H. Li, J. Ou and Z. Zhou, Applications of optical fiber Bragg gratings sensing technology-based smart stay cables, Optics and Lasers in Engineering, 2009, vol. 47, p. 1077-1084. https://doi.org/10.1016/j.optlaseng.2009.04.016.

14. G. Wang, M. Wang, Y. Zhao, Y. Chen and B. Sun, Application of magnetoelastic stress sensors in large steel cables, Smart Structures and Systems, 2006, vol. 2, p. 155-169. https://doi.org/10.1007/1-4020-3661215.

15. S. Sumitro, Y. Matsui, M. Kono, T. Okamoto and K. Fujii, Long span bridge health monitoring system in Japan, Health monitoring and management of civil Infraestructure, Univerity of California, 2001.

16. J. Casas, A combined Method for Measuring Cable Forces: The CableStayed Alamillo Bridge, Spain, Structural Engineering and Structural Dynamics, 1994, vol. 4, $\mathrm{n}^{\circ} 4, \quad$ p. 235-240. https://doi.org/10.2749/101686694780601700. 
17. H. Zui, T. Shinke and Y. Namita, Practical Formulas for Estimation of Cable Tension by Vibration Method, Journal of Structural Engineering, 1996, vol. 122, p. 651-656.

18. J. C. Russel and T. J. Lardner, Experimental Determination of Frequencies and Tension for Elastic Cables, Journal of Engineering Mechanics, 1998, vol. 124, p. 1067-1072. https://doi.org/10.1061/(ASCE)07339399(1998)124:10(1067).

19. W. X. Ren, G. Chen and W. H. Hu, Empirical formulas to estimate cable tension by cable fundamental frequency, Structural Engineering and Mechanics, 2005, vol. 20, p. 363-380. https://doi.org/10.12989/sem.2005.20.3.363.

20. B. H. Kim and P. Taehyo, Estimation of cable tension force using the frequency-based system identification method, Journal of Sound and Vibration, 2007, vol. 304, p. 660-676. https://doi.org/10.1016/.j.jsv.2007.03.012.

21. W. Y. Liao, Y. Q. Ni and G. Zheng, Tension Force and Structural Parameter Identification of Bridge Cables, Advances in Structural Engineering, 2012, vol. 15, p. 983-995. https://doi.org/10.1260/13694332.15.6.983.

22. J. Antoni, Blind separation of vibration components: Principles and demonstrations, Mechanical systems and signal processing, 2005, vol. 19, p. 1166-1180. https://doi.org/10.1016/j.ymssp.2005.08.008.

23. G. Kerschen, F. Poncelet and J. C. Golinval, Physical interpretation of independent component analysis in structural dynamics, Mechanical Systems and Signal Processing, 2007, vol. 21, pp. 1561-1575. https://doi.org/10.1016/j.ymssp.2006.07.009.

24. Y. Yang and S. Nagarajaiah, Output-only modal identification with limited sensors using sparse component analysis, Journal of Sound and Vibration, 2013, vol. 332, p. 4741-4765. https://doi.org/10.1016/i.jsv.2013.04.004.

25. Y. Yang and S. Nagarajaiah, Structural damage identification via a combination of blind feature extraction and sparse representation classification, Mechanical Systems and Signal Processing, 2014, vol. 45, p. 1-23. https://doi.org/10.1016/i.ymssp.2013.09.009.

26. Y. Yang and S. Nagarajaiah, Time-Frequency Blind Source Separation Using Independent Component Analysis for Output-Only Modal Identification of Highly Damped Structures, Journal of Structural Engineering, 2016, vol. 139, p. 1780-1793. https://doi.org/10.1061/(ASCE)ST.1943-541X.0000621.

27. F. Poncelet, G. Kerschen, J. C. Golinval and D. Verhelst, Output-only modal analysis using blind source separation techniques, Mechanical Systems and Signal Processing, 2007, vol. 21, p. 2335-2358. https://doi.org/10.1016/j.ymssp.2006.12.005.

28. F. Abazarsa, S. F. Ghahari, F. Nateghi and E. Taciroglu, Response-only modal identification of structures using limited sensors, Structural control \& 
health monitoring, 2013, vol. 20, p. 987-1006. https://doi.org/10.1002/stc. 1513 .

29. C. Leung, K. Wan, D. Inaudi, X. Bao, W. Habel, Z. Zhou, J. Ou, M. Ghandehari, H. Wu and M. Imai, Optical fiber sensors for civil engineering applications, Materials and Structures, 2015, vol. 48, n 4, p. 871-906.

30. D. Inaudi, Application of optical fiber sensor in civil structural monitoring, Smart Structures and Materials 2001: Sensory Phenomena and Measurement Instrumentation for Smart Structures and Materials. International Society for Optics and Photonics, 2001.

31. B. Glisic, D. Inaudi and S. Vurpillot, Whole lifespan monitoring of concrete bridges, First International Conference on Bridge Maintenance, Safety and Management. IABMAS'02, Barcelona, 2002.

32. B. Glisic, Influence of the gauge length on the accuracy of long-gauge sensors employed in monitoring of prismatic beams, Measurement Science and Technology, 2011, vol. 22, $\mathrm{n}^{\circ} 3$.

33. L. Capineri and A. Bulletti, Ultrasonic Guided-Waves Sensors and Integrated Structural Health Monitoring Systems for Impact Detection and Localization: A Review, Sensors, 2021, vol. 21, nº 2929.

34. B. Glisic, One hundred years of strain sensing in civil structural health monitoring health monitoring, Event12th International Workshop on Structural Health Monitoring: Enabling Intelligent Life-Cycle Health Management for Industry Internet of Things (IIOT), IWSHM 2019, Stanford, 2019.

35. M. F. Bado and. J. R. Casas, A Review of Recent Distributed Optical Fiber Sensors Applications for Civil Engineering Structural Health Monitoring, Sensors, 2021, vol. 21, n 1818. https://doi.org/10.3390/s21051818.

36. D. Inaudi, B. Glisic, Application of distributed Fiber Optic Sensory for SHM, 2nd International Conference on Structural Health Monitoring of Intelligent Infrastructure (SHMII-2'2005), 2005, Shenzhen, China.

37. M. F. Bado, J. R. Casas and G. Kaklauskas, Distributed Sensing (DOFS) in Reinforced Concrete members for reinforcement strain monitoring, crack detection and bond-slip calculation, Engineering Structures, 2021, vol. 226. https://doi.org/10.1016/i.engstruct.2020.111385.

38. P. Lu, N. Lalam, M. Badar, B. Liu, B. T. Chorpening, M. P. Buric and P. R. Ohodnicki, Distributed optical fiber sensing: Review and perspective, Applied Physics Reviews, 2019, vol. 6. https://doi.org/10.1063/1.5113955.

39. I. Laarossi et al., Ultrahigh Temperature Raman-Based Distributed Optical Fiber Sensor With Gold-Coated Fiber, IEEE Journal of Selected Topics in Quantum Electronics, 2017, vol. 23, no. 2, pp. 296-301, https://doi.org/10.1109/JSTQE.2016.2633821.

40. L. Schenato, A Review of Distributed Fiber Optic Sensors for GeoHydrological Applications, Applied Sciences, 2017, 7, 896; https://doi.org/10.3390/app7090896.

41. C. Eschmann and T. Wundsam, Web-Based Georeferenced 3D Inspection and Monitoring of Bridges with Unmanned Aircraft Systems, Journal of 
Surveying Engineering, 2017, vol. 143, $\mathrm{n}^{\circ} \quad 3$. https://doi.org/10.1061/(ASCE)SU.1943-5428.0000221.

42. P. Olaszek, Investigation of the dynamic characteristic of bridge structures using a computer vision method, Measurement, 1999, vol. 25, $\mathrm{n}^{\circ} 3, \mathrm{p}$. 227-236. https://doi.org/10.1016/S0263-2241(99)00006-8.

43. S. Patsias and W. J. Staszewskiy, Damage Detection Using Optical Measurements and Wavelets, Structural Health Monitoring, 2002, vol. 1, $\mathrm{n}^{\circ}$ 1, p. 5-22. https://doi.org/10.1177/147592170200100102.

44. J. Yoshida, M. Abe, S. Kumano and Y. Fujino, Construction of a measurement system for the dynamic behaviors of membrane by using image processing, International Conference on Textile Composites and Inflatable Structures. Structural Membranes 2003.

45. H.-C. Chun, J. Liang, S. Kushiyama and M. Shinozuka, Digital image processing for nonlinear system identification, International Journal of Non-Linear Mechanics, 2004, vol. 39, $\mathrm{n}^{\circ}$ 5, p. 691-707. https://doi.org/10.1016/S0020-7462(03)00021-0.

46. C. C. Chang and Y. Ji, Sensing of low-frequency vibration using photogrammetric technique, Structural Health Monitoring and Intelligent Infrastructure - Proceedings of the 2nd International Conference on Structural Health Monitoring of Intelligent Infrastructure, SHMII 2005, Shenzhen, 2006.

47. Y. F. Ji and C. C. Chang, Nontarget Image-Based Technique for Small Cable Vibration Measurement, Journal of Bridge Engineering, 2008, vol. 13, $\mathrm{n}^{\circ} \quad 1, \quad$ p. 34-42. https://doi.org/10.1061/(ASCE)10840702(2008)13:1(34).

48. J. Manterola-Armisen, A. Martínez-Cutillas and B. Martín-Martínez, Puente sobre el río Tajo en el embalse de Alcántara para ferrocarril de alta velocidad, Revista de Obras Públicas, 2015, n 3562, p. 83-92.

49. Viaducto de Alcántara, un arco de 324 metros de luz para salvar el Tajo, 2013. https://www.mundo-ferroviario.es.

50. J. Dally and W. F. Riley, Experimental Stress Analysis, New York: McGraw-Hil Book Company, 1978.

51. M. J. Pantaleón and G. Gutiérrez, Apuntes de extensometría y fotoelasticidad, Universidad de Cantabria, 1983.

52. S. González, J. Désir, P. Habib and C. Vieira, Theorical and experimental checking of remaining forces in external prestessing tendons, Hormigón y Acero, 2007, vol. 58, n 245.

53. D. Ferreras, R. Martí and J. Somalo, Inspección especial Pasarela Atirantada El Perelló, Hormigón y Acero, 2012, vol. 63, n 266, p. 67-78.

54. C. Gentile and A. Saisi, Ambient vibration testing and conditon assessment of the Padermo iron arch bridge (1889), Construction and Building Materials, 2011, vol. 25, $\mathrm{n}^{\circ}$ 9, p. 3709-3720. https://doi.org/10.1016/i.conbuildmat.2011.04.019. 
55. A. Barrero, G. Alonso, J. Meseguer and M. Astiz, Ensayos en túnel de viento de un modelo aerolástico del arco del Puente sobre el río Tajo. Arcos de Alconetar, Hormigón y Acero, 2007.

56. G. Henderson, U.S. Department of Transportation. Federal Highway Administration, Wind-Induced Vibration of Stay Cables, 2007.

57. G. Arioli and F. Gazzola, Commun Nonlinear Sci Numer Simulat, Torsional instability in suspension bridges: The Tacoma Narrows Bridge case, 2017 vol. 42, p. 342-357.

58. M. A. Astiz, Wind-Induced Vibrations of the Alconétar Bridge, Spain, Structural Engineering International, 2018, vol. 20, $\mathrm{n}^{\circ}$ 2, p. 195-199. https://doi.org/10.2749/101686610791283696.

59. H. Fei. D. Zichen and. D. Danhui, Exact dynamic analysis of multisegment cable systems, Mechanical Systems and Signal Processing, 2021, vol. 146, n 107053. https://doi.org/10.1016/.ymssp.2020.107053.

60. General Highway Administration - Government of Spain, Recomendaciones para la realización de pruebas de carga de recepción en puentes de carretera, 1999. 